\section{Prospective birth cohort in a hyperendemic dengue area in Northeast Brazil: methods and preliminary results}

\author{
Coorte de nascimento prospectiva em uma área \\ hiperendêmica em dengue no Nordeste do Brasil: \\ métodos e resultados preliminares \\ Cohorte de nacimientos en un área hiperendémica \\ en dengue en el nordeste de Brasil: métodos y \\ resultados preliminares
}

Cynthia Braga 1,2

Maria de Fátima Pessoa Militão de

Albuquerque 1

Marli Tenório Cordeiro 1

Priscila M. S. Castanha 1

Anita Ramesh 3

Neal Alexander 3

Maria Júlia G. de Mello 2

Ernesto T. A. Marques Jr. 1,4

Celina M. Turchi Martelli 1,5

\begin{abstract}
Dengue cases have increased in younger age groups in Brazil. Maternal anti-dengue antibodies can have a protective effect in the first months of life, but their decline can increase the risk of severe dengue. A prospective birth cohort was established in 2011-2012 in the city of Recife, Pernambuco State, Brazil, to determine the incidence of serotype-specific dengue infection and the kinetics of transferred maternal anti-dengue antibodies in the first years of life. This article describes the design, methods and preliminary results of this cohort study. 354 children underwent clinical and laboratory monitoring for two years, with $15 \%$ losses to follow-up. The overall rate of new infections was approximately $10 \%$ in the first year of follow-up. Information on the force of serotype-specific dengue infection and the evaluation of transferred maternal antibodies can contribute to understanding dengue etiopathogenesis.
\end{abstract}

1 Centro de Pesquisas Aggeu Magalhães, Fundação Oswaldo Cruz, Recife, Brasil. 2 Instituto de Medicina Integral Prof. Fernando Figueira, Recife, Brasil. 3 Department of Infectious Disease Epidemiology, London School of Hygiene and Tropical Medicine, London, U.K.

${ }_{4}^{4}$ Center for Vaccine Research University of Pittsburgh, Pittsburgh, U.S.A. 5 Instituto de Patologia Tropical e Saúde Pública Universidade Federal de Goiás, Goiânia, Brasil.

\author{
Correspondence \\ C. Braga \\ Centro de Pesquisas Aggeu \\ Magalhães, Fundação \\ Oswaldo Cruz. \\ Av. Moraes Rego s/n, Recife \\ PE 50670-420, Brasil. \\ braga@cpqam.fiocruz.br
}

Passive Immunization; Dengue; Cohort Studies 


\section{Introduction}

Dengue fever, caused by exposure to the dengue virus (DENV), is a serious and growing public health problem worldwide, particularly amongst those residing in urban areas of tropical and subtropical countries 1. In Brazil, where all four dengue serotypes (DENV-1-4) circulate, an increasing trend in the incidence of dengue has been observed, along with increases in the number of hospitalizations and deaths from the disease 2 . Severe dengue is a main cause of hospitalization and death among children in many Asian and Latin American countries 1,3.

There is a lack of consensus on pathogenesis models for severe dengue in infants. In the first six months of life, high levels of transplacentally transferred maternal anti-DENV antibodies appear to protect infants from symptomatic dengue 4 . However, a progressive decline in these antibodies after birth may increase the risk of developing severe dengue among infants aged 6-12 months 4,5. It has been postulated that an immunological window characterized by subneutralizing levels of transplacentally transferred maternal anti-DENV antibodies is involved in the development of severe dengue in infants $4,5,6$. This has been confirmed by studies conducted in Southeast Asia, where severe dengue in children in the first months of life often occurs in primary dengue virus infection $3,5,7$.

Prospective cohort studies have proved important in understanding the epidemiology and immunopathogenesis of dengue fever in pediatric populations $6,8,9,10$. However, few studies to date have involved children aged less than four years and only one published study has included Latin American populations 11. There is a need to better understand - e.g., via birth cohort studies - dengue incidence, the kinetics of transplacentally transferred maternally anti-DENV antibodies and their relationship to the duration of protection against dengue in children in the Brazilian context.

Therefore, we set up a prospective birth cohort study in the city of Recife, a dengue hyperendemic area in northeastern Brazil, between March 2011 and May 2012. This paper describes the design, methods and the field implementation of this cohort study. We also present the serotype-specific epidemiological profile of the maternal-child pairs, the preliminary results of follow-up of acute febrile syndrome and the frequency of dengue infection in the first year of life.

\section{Methods}

The birth cohort was established at the Instituto de Medicina Integral Prof. Fernando Figueira (IMIP) a publicly funded teaching hospital in the city of Recife. The parturient enrolment occurred in the maternity ward of IMIP, a large public maternity hospital in Northeast Brazil (around 5,000 deliveries per year).

Recife, the capital of Pernambuco state, has a population of approximately 1.7 million inhabitants and an annual average of 20,000 live births (Brazilian Institute of Geography and Statistics. http://www.cidades.ibge.gov.br/xtras/ perfil.php?lang=\&codmun $=261160 \&$ search $=$ per nambuco|recife, accessed on 29/Sep/2014; Brazilian Ministry of Health. http://svs.aids.gov.br/ cgiae/sinasc/, accessed on 24/Sep/2014). The first cases of dengue in Recife were recorded in 1987. Since then, the city has experienced major epidemics of serotypes DENV-1, 2 and 3 12. Between 2010 and 2014 the Secretary of Health of Recife recorded 27,874 dengue cases, of which $15.2 \%(4,237)$ occurred in children aged less than 15 years (Secretary of Health of Recife, personal communication, 2014). Currently, all four DENV serotypes co-circulate in the Recife metropolitan region, but consistent with other endemic sites there has been a fluctuation between predominant serotypes 13. During the period in which this cohort study was conducted, DENV-4 and DENV-1 serotypes have predominated in the region (Health Department of Pernambuco, personal communication, 2012).

Parturients included in the study were clinically assessed as having low risk pregnancies, resident in Recife, and agreed to have their children followed up for at least one year.

Children were followed during their first 24 months of age between May 2011 and June 2014; which included the time period of parturient recruitment and follow-up of children. Neonates were randomly allocated into two groups and examined after birth as follows: (a) Group 1 months 2, 6, 10 and 18; (b) Group 2 - months 4, 8, 12 and 24 (Figure 1). The study also included the screening of febrile syndromes during follow-up, in order to detect acute DENV infection.

In the child cohort, the main outcome was the detection of recent or current DENV infection by immunoglobulin M (IgM) capture ELISA (enzyme linked immunosorbent assay) and/or RT-PCR (reverse transcription polymerase chain reaction). Symptomatic dengue infection was defined as a positive result (IgM or RT-PCR) along with the report of current or previous acute febrile syndrome between birth and the first follow up (2-4 months); in the second (4-8 months) 


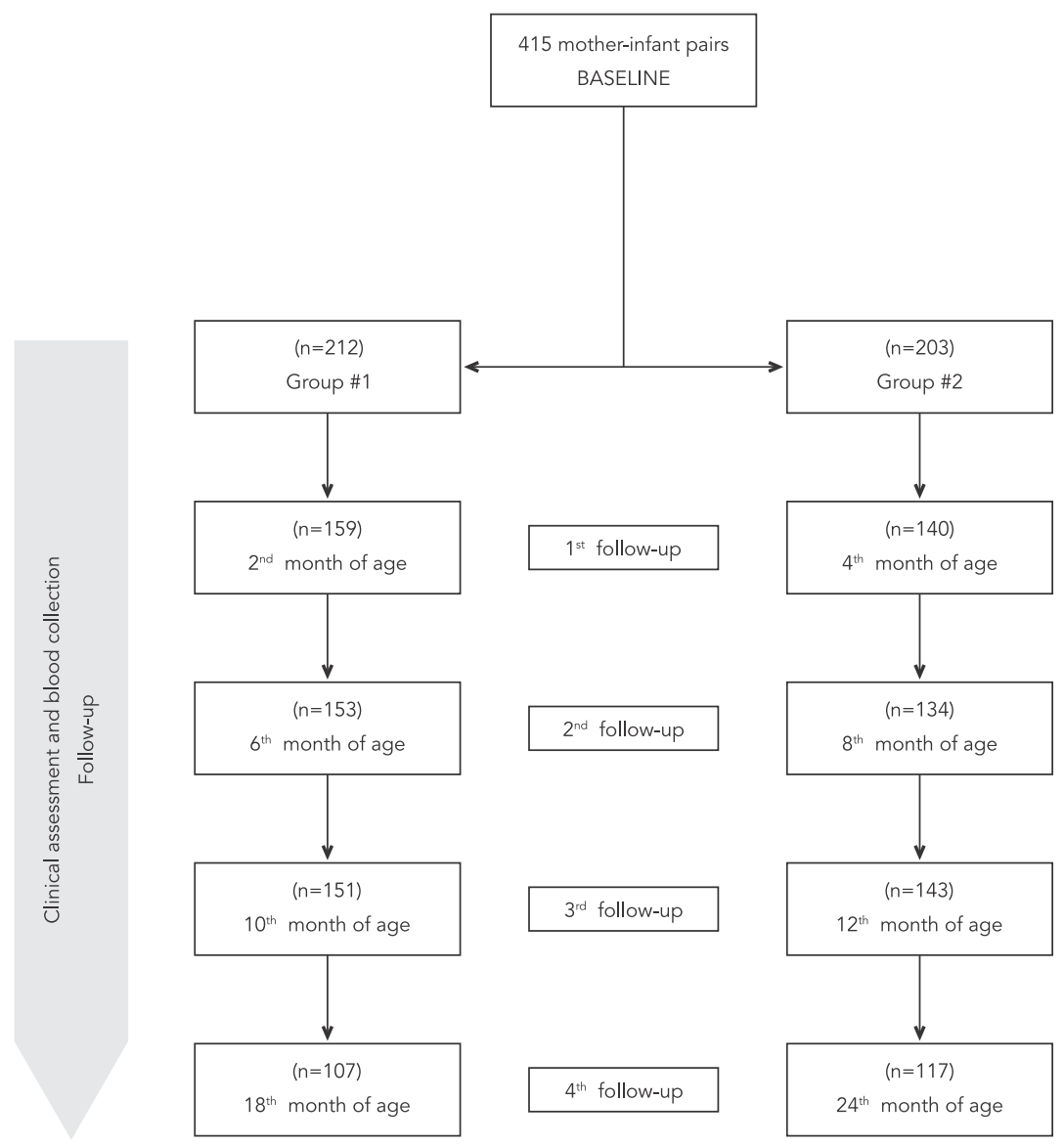

and third (8-12 months) follow up evaluations. Asymptomatic dengue infection was defined by the detection of anti-dengue IgM antibodies and no report of previous or current occurrence of acute febrile syndrome.

The sample size was calculated based on an assumed incidence rate of 0.05 , with a margin of error (two-tailed) of 0.05 , yielding a sample size of 30714 . To account for up to $25 \%$ losses to follow-up, the target number of pregnant women to be recruited was 375 .

Table 1 shows the measurements obtained during cohort enrolment, follow-up and evaluation of acute febrile events between scheduled visits during follow-up. In addition, it shows the laboratory tests performed at each phase of the study. The parturients were contacted at the time of hospital admission in order to check for the eli- gibility. They were informed about the study objectives, invited to participate and asked to read and sign a consent form. Interviews were conducted by trained nurses using a standardized questionnaire. Maternal blood samples (10mL) were collected after the enrollment interview to confirm current and previous dengue infection. Following delivery, a $10 \mathrm{~mL}$ blood cord sample was obtained to assess current dengue infection as well as maternally transferred total and specific anti-DENV antibodies to the neonates. We previously reported the high seroprevalence of anti-dengue IgG antibodies among parturients enrolled in this cohort 15 .

The clinical evaluations were carried out at IMIP by two experienced pediatricians who recorded clinical data and anthropometric measures of the child in standardized questionnaires. 
Table 1

Data collected at baseline, follow-up and surveillance of episodes of febrile syndromes in the birth cohort study.

\begin{tabular}{|c|c|}
\hline Phase & Measurements \\
\hline \multicolumn{2}{|l|}{ Baseline (2011-2012) } \\
\hline \multirow[t]{3}{*}{ Maternal data (at delivery) } & $\begin{array}{l}\text { Sociodemographic: age, skin color (white, black, mixed race or indigenous), level of schooling (in years), } \\
\text { family income (in multiples of the minimum wage) }\end{array}$ \\
\hline & $\begin{array}{l}\text { Clinical: smoking status, self-report of fever or dengue fever during current pregnancy, episodes of } \\
\text { sexual transmitted diseases, urinary tract infections, yellow fever vaccination status, type of delivery, }\end{array}$ \\
\hline & $\begin{array}{l}\text { placenta abnormalities } \\
\text { Laboratory: serologic tests (DENV-specific IgM and IgG, DENV specific IgG-subclass, PRNT); reverse } \\
\text { transcriptase - polymerase chain (RT-PCR) }\end{array}$ \\
\hline \multirow[t]{3}{*}{ Newborn data } & Clinical: gestational age, Apgar score (1st and 5th min), sex, birth weight \\
\hline & $\begin{array}{c}\text { Laboratory (umbilical cord): serologic tests (DENV-specific IgM and IgG, DENV specific lgG-subclass, } \\
\text { PRNT); RT-PCR (carried out when the parturient reported fever in the seven days preceding the } \\
\text { childbirth) }\end{array}$ \\
\hline & Maternal and cord blood samples taken, serum aliquots stored at $-80^{\circ} \mathrm{C}$ \\
\hline \multicolumn{2}{|c|}{$\begin{array}{l}\text { Scheduled follow-up and evaluation of } \\
\text { acute febrile event (2011-2014) }\end{array}$} \\
\hline \multirow[t]{7}{*}{ Child data } & $\begin{array}{c}\text { Clinical data: vaccination status, breastfeeding (exclusive, mixed, not breastfed), signs and symptoms } \\
\text { during the consultation (fever, diarrhea, rash, cough, dyspnea, runny nose and swelling), febrile illness } \\
\text { since the last consultation }\end{array}$ \\
\hline & Anthropometric measures: weight, length \\
\hline & Vital signs: temperature, heart and respiratory rate \\
\hline & Blood sample taken, serum aliquots stored at $-80^{\circ} \mathrm{C}$ \\
\hline & Laboratory tests: serologic tests (DENV-specific IgM and IgG, DENV specific IgG-subclass, PRNT); \\
\hline & RT-PCR *, blood cell count *, hematocrit * \\
\hline & $\begin{array}{l}\text { Laboratory assays: enhancing activity of maternal transferred antibodies will be tested in a random } \\
\text { subset of the cohort }\end{array}$ \\
\hline
\end{tabular}

* Suspected dengue case or fever of unknown origin.

After maternity discharge, a member of the research team contacted parents or guardians via telephone to schedule the follow-up evaluations of their children. They were also asked to contact the research team if the child had fever for more than 24 hours to provide medical care and investigate whether the acute febrile was related to dengue infection.

A suspected dengue case was defined as the presence of fever and at least two more of the following symptoms: drowsiness, refusal of intake food and fluids, vomiting, diarrhea or loose stools, according to the Brazilian Ministry of Health 16. In addition, children with fever without localizing signs and symptoms (example, otitis, pneumonia and others infections) were also considered as likely dengue cases and screened for dengue infection. Therefore, both groups (suspected dengue cases and fever without localizing signs and symptoms) had blood samples (2mL) taken to assess acute dengue infection through DENV IgM and RT-PCR. The guardians were asked to return to the clinic after 48 to 72 hours for another clinical evaluation by the pediatrician. They were also instructed to contact the research team if the child's clinical status worsened.

A venous blood sample $(2 \mathrm{~mL})$ was obtained by an experienced phlebotomist 15 minutes after topical application of anesthetic (lidocaine gel) and directly collected into $5 \mathrm{~mL}$ Vacutainer tubes. Serum samples were separated and stored into cryovials at $-80^{\circ} \mathrm{C}$. All blood samples collected during the cohort enrollment (maternalchild pairs) and child follow-up are being tested for anti-dengue IgG via indirect Enzyme-Linked Immunosorbent Assay-ELISA (Panbio, Brisbane, Australia) and anti-dengue IgM via capture ELISA (PanBio and Focus Diagnostic, Cypress, USA). Dengue cases tracked in febrile infants were laboratory-confirmed by reverse-transcriptase polymerase chain reaction (RT-PCR) and IgM-ELISA. RT-PCR was performed according to a standardized protocol described elsewhere ${ }^{17}$. Viral RNA 
was extracted from serum samples using QIAquick PCR purification kits (Qiagen, Valencia, USA).

Serotype-specific anti-DENV antibodies are being assessed by a plaque reduction neutralization test (PRNT) performed following a modified protocol from Morens et al. 18,19. This PRNT assay has been carried out using virus strains isolated from dengue cases diagnosed in the study setting (Pernambuco state). DENV-1 (PE/97-42735), DENV-2 (PE/95-3808), DENV-3 (PE/02-95016) and DENV-4 (PE/0081) were provided by the Public Health Laboratory of Pernambuco state (LACEN-PE). All laboratory assays and serological tests are being performed at the Virology Laboratory (LAVITE) at the Aggeu Magalhães Research Center, Oswaldo Cruz Foundation (CPqAM/ Fiocruz) in Recife, and in collaboration with the Center for Vaccine Research at the University of Pittsburgh (Pittsburgh, USA).

The standardized questionnaires for both parturients and children were entered into a secure electronic web-based platform (http:/ / www. cpqam.fiocruz.br/questdengue/). Data entry has been performed in parallel with data collection (completed) and laboratory testing (ongoing). The database is held on an SQL Server 2000 (Microsoft Corp.) using GeneXus software, version 7.5 (http://www.genexus.com/); this server is maintained at CPqAM/Fiocruz. Stata version 12 (StataCorp LP, College Station, USA) is being used for data analysis.

The maternal and umbilical cord dengue serotype-specific antibodies titers will be estimated using non-linear regression and the values will be log-transformed. A subset of the children cohort will be randomly selected to assess the kinetics of transplacentally transferred maternal antiDENV antibodies and antibody enhancement via flow cytometry.

The protocol was approved by Ethics Research Committee of CpqAM/Fiocruz (59/10; CAAE-0061.0.095.000-10) and the IMIP (no 2744 Dec 26, 2010).

\section{Results}

Figure 1 illustrates the cohort enrollment; follow up, including the number of children seen at each scheduled examination. From 934 parturients that fulfilled the inclusion criteria, 417 women were recruited. Of the parturients recruited, two were transferred to another hospital yielding a total of 415 parturients enrolled.

Of the 415 children whose mothers were recruited into the cohort, 354 (85.3\%) were examined in at least one of the four scheduled clinical assessments, resulting in $14.7 \%$ of individuals lost to follow-up (overall attrition rate). Most losses to follow-up were due to refusal, followed by difficulties in tracing cohort participants because of incorrect address provision and/or a change in place of residence. Table 2 shows the comparative analysis of the baseline characteristics of children who were followed and not followed in this dengue birth cohort; there were no statistically significant differences in the characteristics between these groups.

Table 3 presents the main clinical and laboratory characteristics of the cohort. The determination of the DENV serotype-specific profile of the parturients showed that monotypic infection by DENV-3 (52\%) predominated, followed by dual infection by DENV-3 and DENV-4 (29.3\%).

Dengue infection (dengue IgM capture ELISA and/or RT-PCR) varied from $7.3 \%$ to $10.7 \%$ in the second and third follow-up. The proportion of dengue infections that were symptomatic was $37 \%$, therefore the ratio of symptomatic to asymptomatic dengue infection in one-year follow up was 1:1.7. These preliminary results were estimated by anti-dengue IgM-ELISA (Focus Diagnostic, Cypress, USA).

Regarding acute febrile surveillance, 56 children were registered as a suspected dengue case or fever of unknown origin and 15 (26.7\%) were virologically-confirmed by RT-PCR. Of note, we identified children infected with DENV-1 $(\mathrm{n}=$ 5), DENV-2 $(\mathrm{n}=2)$, DENV-3 $(\mathrm{n}=2)$ and DENV-4 $(n=6)$ by RT-PCR in the first year of the cohort. None of the infected children have evolved to severe dengue.

\section{Discussion}

Our preliminary results point out an overall rate of $10 \%$ new dengue infections (Ig M-ELISA or RT-PCR) during the first year of follow-up in this birth cohort assembled in the Northeast of Brazil, suggesting a high exposure of DENV virus in early life. The ratio of symptomatic to asymptomatic dengue infection of 1:1.7 found in this study, reinforces the knowledge of a higher frequency of unapparent infection compared with symptomatic infection detected by active surveillance 20 . During the child follow up, approximately $25 \%$ of clinically suspected dengue cases were virologically-confirmed. Of note, all serotypes (DENV-1 to DENV-4) were detected pointing out the simultaneous co-circulation of the different serotypes that is compatible with hyperendemicity in the study area 21 .

Half of the studied parturients had monotypic infection by DENV-3 and around $30 \%$ had dual infection by DENV-3 and DENV-4. This immune 
Table 2

Comparison of maternal and child characteristics at baseline stratified by children followed and those not followed in the birth cohort study.

\begin{tabular}{|c|c|c|c|c|}
\hline Characteristics & $\begin{array}{l}\text { Followed } \\
(n=354)\end{array}$ & $\begin{array}{l}\text { Not followed } \\
\qquad(n=60)\end{array}$ & $\begin{array}{l}\text { Difference } \\
(95 \% \mathrm{Cl})\end{array}$ & p-value \\
\hline \multicolumn{5}{|l|}{ Maternal } \\
\hline Age in years [Mean (SD)] & $23.5(6.2)$ & $24.5(6.3)$ & $-0.9(-2.7 ; 0.7)$ & 0.866 * \\
\hline \multicolumn{5}{|l|}{ Self-identified race } \\
\hline Mixed & $238(67.2)$ & $40(66.7)$ & $0.3(-6.9 ; 7.6)$ & 0.931 ** \\
\hline Others & $116(32.8)$ & $20(33.3)$ & & \\
\hline \multicolumn{5}{|c|}{ Individual income (multiples of minimum wage) [n (\%)] } \\
\hline No paid work & $209(62.2)$ & $31(56.4)$ & $2.9(-4.2 ; 10.2)$ & $0.409 * *$ \\
\hline$\geq 1$ & $127(37.8)$ & $24(43.6)$ & & \\
\hline \multicolumn{5}{|l|}{ Years of schooling [n (\%)] } \\
\hline$>8$ & $202(57.1)$ & $35(58.3)$ & $-0.6(-7.7 ; 6.2)$ & 0.854 ** \\
\hline$\leq 8$ & $152(42.9)$ & $25(41.7)$ & & \\
\hline \multicolumn{5}{|l|}{ 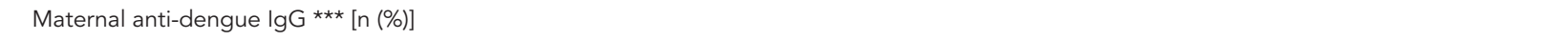 } \\
\hline Positive & $328(95.9)$ & $56(93.3)$ & & \\
\hline Negative & $14(4.1)$ & $4(6.7)$ & $7.6(-11.9 ; 27.2)$ & 0.374 ** \\
\hline \multicolumn{5}{|l|}{ Maternal anti-dengue IgM \# [n (\%)] } \\
\hline Positive & $57(16.6)$ & $9(15.0)$ & & \\
\hline Negative & $287(83.4)$ & $51(85.0)$ & $1.4(-7.7 ; 10.6)$ & $0.761 * \star$ \\
\hline \multicolumn{5}{|l|}{ Children } \\
\hline Gestational age (weeks) [mean (SD)] & $39.3(1,1)$ & $39.4(1.2)$ & $-0.093(-0.4 ; 0.2)$ & $0.721 * \star$ \\
\hline Birth weight (g) [mean (SD)] & $3,293(365,8)$ & $3,324(469,5)$ & $\begin{array}{c}-30.6(-135.6 \\
74.3)\end{array}$ & $0.716 * \star$ \\
\hline \multicolumn{5}{|l|}{$\operatorname{Sex}[n(\%)]$} \\
\hline Female & $180(50.9)$ & $30(50.0)$ & & \\
\hline Male & $174(49.2)$ & $30(50.0)$ & $0.4(-6.4 ; 7.2)$ & 0.903 ** \\
\hline \multicolumn{5}{|l|}{ Anti-dengue IgG umbilical cord * [n (\%)] } \\
\hline Positive & $309(96.3)$ & $54(96.4)$ & & \\
\hline Negative & $12(3.7)$ & $2(3.6)$ & $-0.6(-9.3 ; 18.1)$ & $0.951 * \star$ \\
\hline
\end{tabular}

95\% Cl: 95\% confidence interval.

* t test;

** Pearson chi-squared;

*** Panbio, Brislaine, Australia;

\# Focus Diagnostic, Cypress, USA.

profile reflects the epidemiological scenario of co-circulation of different serotypes in Recife, with the predominant circulation of serotype DENV-3 between 2002 and 2006, and the recent introduction and predominance of serotype 4 in the last three years 2,17. This maternal anti-dengue immune profile seems to be different from studies conducted in pregnant women in Asian countries where the majority of pregnant women were immune against two or more DENV serotypes 5,8,9. In these Asian countries, unlike Brazil ${ }^{2}$, a high proportion of dengue cases in infants progress to severe dengue forms 3,21 . The difference in the maternal anti-dengue immune pro- file could be attributed to the diverse Brazilian epidemiological scenario. In our setting, a previous modeling study showed that dengue is hyperendemic and that the accumulation of multitypic immunity in adults could lead to a possible shift of dengue hemorrhagic fever to children in the future 12 .

We present in the current paper the preliminary results of the first birth cohort study conducted to investigate the incidence of pediatric dengue infection in a large urban area in the Northeast of Brazil. Few such cohort studies have been published in Latin America 22,23. This cohort will allow an in-depth analysis of the 


\section{Table 3}

Maternal and child clinical and laboratorial characteristics in the Brazilian dengue birth cohort study $(\mathrm{N}=354)$.

\section{Characteristics}

\section{Baseline}

Maternal

Dengue serotype specific antibodies $(\lg G) *[n(\%)]$

None

37 (10.8)

DENV-3

179 (52.3)

DENV-4

$1(0.29)$

DENV-1/DENV-2

$2(0.6)$

DENV-1/DENV-3

5 (1.5)

DENV-2/DENV-3

$2(0.6)$

DENV-2/DENV-4

$1(0.3)$

DENV-3/DENV-4

100 (29.3)

DENV-1/DENV-2/DENV-3

4 (1.2)

DENV-1/DENV-3/DENV-4

4 (1.2)

DENV-2/DENV-3/DENV-4

$3(0.9)$

DENV-1/DENV-2/DENV-3/DENV-4

4 (1.2)

Frequency of serotype-specific dengue infection * [n (\%)]

DENV-1

$19(5.5)$

DENV-2

18 (4.7)

DENV-3

$302(87.8)$

DENV-4

$113(32.9)$

Number of previous dengue infection * [n (\%)]

None

37 (10.8)

$180(52.6)$

2

110 (32.2)

3-4

$15(4.4)$

Children

Anti-dengue IgG antibodies (umbilical cord) ** [n (\%)]

Positive

309 (96.3)

Negative

$12(3.7)$

Anti-dengue IgM *** and/or RT-PCR \# [positive/examined (\%)]

1 st follow-up

$29 / 299(9.7)$

2nd follow-up

$21 / 287(7.3)$

3rd follow-up

$34 / 294$ (11.5)

Acute febrile syndrome [events/total (\%)]

Children with febrile event

$138 / 354$ (38.9)

Suspected dengue cases among febrile events

$56 / 138$ (40.5)

Virologically-confirmed dengue cases among suspected

$15 / 56(26.7)$

DENV serotypes \#

DENV-1

DENV-2

DENV-3

DENV-4

6

* Plaque reduction neutralization test;

** Panbio, Brislaine, Australia;

*** Focus Diagnostic, Cypress, USA;

\# Reverse transcriptase-polymerase chain reaction. 
immunology and dynamics of maternally-transferred antidengue antibodies to be assessed in further studies.

Data on the decay of maternally-transferred dengue antibodies during early life, measured in short time intervals (every two months) are crucial for assessing the rate of loss cross-immunity and dengue incidence during the first year of life. On the other hand, maintaining high compliance rates in order to ensure the internal validity of the results is one of the main challenges in conducting cohort studies (mainly those involving clinicinvasive visits) 24 . To minimize a potentially high attrition rate due to serial clinical investigations and blood sample collections, the cohort was divided into two groups with different follow-up schedules that captured clinical data and blood samples every two months during the first year of life and every six months during the second. This approach allowed for sequential data collection on a large number of age bands, i.e., every two months in the first year and at two different points (months 18 and 24) in the second year. In this regard, a $15 \%$ rate of attrition obtained in our study is considered acceptable in epidemiological cohorts 25 . In addition, the comparative analysis between the baseline characteristics of the children followed and those not followed showed no significant differences between these groups, which reduces the chance of selection bias.

Since the majority of women enrolled in this hospital-based study are from economically-deprived areas, it is possible that the incidence of dengue infection in the current study might be overestimated if extrapolated to the entire city. Another potential concern related to external validity is that the study population was a sample of parturients and neonates who were recruited at a large public maternity hospital; therefore, some data may not be representative of the general population in Recife and its surroundings or other regions with diverse dengue epidemiological patterns.

Some limitations related to diagnostic and laboratory methods also need to be considered. For instance, IgM through Capture ELISA methods have a high likelihood of producing falsepositive results, leading to difficulty in accurately measuring the incidence rate based on the detection of specific antibodies 26,27. In addition, infor- mation on the accuracy of these tests is lacking, as well as about the duration over which IgM specific antibodies can be detected in neonates and infants. To overcome these limitations, we used those assays with the greatest accuracy in terms of sensitivity and specificity 27 . However, these commercial IgM-based assays produced discrepant results when tested on cord samples at baseline 15 . It is generally agreed that IgM wanes to undetectable levels between two to six months after the onset of infection, so we expected to be able to capture most of the primary infections occurring during the observation period 28,29. Because IgM antibody response to DENV is lower in secondary than primary infections 29,30 , we may not be able to capture some secondary infections among the infants. Still, considering the short time of exposure in this birth cohort when compared to the adult population, secondary infection is likely to be a rare event in this age group. Given the above and as proposed by Kassanjee et al. 31 , it is necessary to consider both the mean duration of the presence of detectable levels of IgM as well as the expected rates of false IgM positives when calculating incidence in this study. Issues related to the severity of dengue disease were out of the scope of this cohort study considering the low frequency of this event among children in our setting.

Our cohort design will bring attention to the serotype-specific force of infection in the early years of life in Brazil. Of note, this study has shown the feasibility of establishing birth cohorts in our region, as well as some innovative methodological approaches employed to minimize loss to follow up in a birth cohort. Finally, the study also allowed establishing a biobank to investigate biological events (the transference of DENVspecific IgG isotypes, enhancement activity, and complement activation mediated by maternallyacquired antibodies). These issues are essential for a better understanding of the dynamic of maternal child immunity related to dengue infection in the Brazilian epidemiological context. We highlight the potential of birth cohorts with extended follow up to provide information on dengue incidence, and other viral infections in different epidemiological scenarios to complement the official surveillance. 


\section{Contributors}

C. Braga participated in the design, planning and coordination of data collection, data analysis plan and writing of the paper. M. F. P. M. Albuquerque participated in the study design, plan of analysis and drafting the article. M. T. Cordeiro participated in the planning, coordination of the activities of processing and analysis of laboratory tests and writing the article. P. M. S. Castanha participated in the planning, coordination of the activities of processing and analysis of laboratory tests and writing the article. A. Ramesh, N. Alexander, M. J. G. Mello, E. T. A. Marques Jr. and C. M. T. Martelli participated in the study design, plan of analysis and drafting the article.

\section{Acknowledgments}

The authors of this study would like to thank Dr. Clarence Tam and Dr. Lyda Osorio for their methodological input during the inception of this cohort. We would also like to thank the Brazilian National Research Council (CNPq), which provided financial support to C. Braga (304174/2014-9), M. F. P. M. Albuquerque (308491/20130), and C. M. T. Martelli (306489/2010-4). N. Alexander receives salary support from the United Kingdom Medical Research Council (MRC) and the Department for International Development (DFID) (MR/K012126/1).

\section{References}

1. World Health Organization. Global strategy for dengue prevention and control. Geneva: World Health Organization; 2012.

2. Teixeira MG, Siqueira Jr. JB, Ferreira GL, Bricks L Joint G. Epidemiological trends of dengue disease in Brazil (2000-2010): a systematic literature search and analysis. PLoS Negl Trop Dis 2013; 7:e2520.

3. Halstead SB, Lan NT, Myint TT, Shwe TN, Nisalak A, Kalyanarooj S, et al. Dengue hemorrhagic fever in infants: research opportunities ignored. Emerg Infect Dis 2002; 8:1474-9.
4. Kliks SC, Nimmanitya S, Nisalak A, Burke DS. Evidence that maternal dengue antibodies are important in the development of dengue hemorrhagic fever in infants. Am J Trop Med Hyg 1988; 38:411-9.

5. Simmons CP, Chau TN, Thuy TT, Tuan NM, Hoang DM, Thien NT, et al. Maternal antibody and viral factors in the pathogenesis of dengue virus in infants. J Infect Dis 2007; 196:416-24.

6. Endy TP. Human immune responses to dengue virus infection: lessons learned from prospective cohort studies. Front Immunol 2014; 5:183. 
7. Nguyen TH, Lei HY, Nguyen TL, Lin YS, Huang KJ, Le BL, et al. Dengue hemorrhagic fever in infants: a study of clinical and cytokine profiles. J Infect Dis 2004; 189:221-32.

8. Pengsaa K, Luxemburger C, Sabchareon A, Limkittikul K, Yoksan S, Chambonneau L, et al. Dengue virus infections in the first 2 years of life and the kinetics of transplacentally transferred dengue neutralizing antibodies in thai children. J Infect Dis 2006; 194:1570-6.

9. Chau TN, Hieu NT, Anders KL, Wolbers M, Lien le B, Hieu LT, et al. Dengue virus infections and maternal antibody decay in a prospective birth cohort study of Vietnamese infants. J Infect Dis 2009; 15:1893-900.

10. Libraty DH, Acosta LP, Tallo V, Segubre-Mercado E, Bautista A, Potts JA, et al. A prospective nested case-control study of dengue in infants: rethinking and refining the antibody-dependent enhancement dengue hemorrhagic fever model. PLoS Med 2009; 6:e1000171.

11. Gordon A, Kuan G, Mercado JC, Gresh L, Aviles W, Balmaseda A, et al. The Nicaraguan pediatric dengue cohort study: incidence of inapparent and symptomatic dengue virus infections, 2004-2010. PLoS Negl Trop Dis 2013; 7:e2462.

12. Rodriguez-Barraquer I, Cordeiro MT, Braga C, de Souza WV, Marques ET, Cummings DAT. From reemergence to hyperendemicity: the natural history of the dengue epidemic in Brazil. PLoS Negl Trop Dis 2011; 7:e2126.

13. Messina JP, Brady OJ, Scott TW, Zou C, Pigott DM, Duda KA, et al. Global spread of dengue virus types: mapping the 70 year history. Trends Microbiol 2014; 22:138-46.

14. Kirkwood B, Sterne J. Essential medical statistics. Oxford: Wiley-Blackwell; 2003.

15. Leite RC, Souza AI, Castanha PM, Cordeiro MT, Martelli CT, Ferreira AL, et al. Dengue infection in pregnancy and transplacental transfer of antidengue antibodies in Northeast, Brazil. J Clin Virol 2014; 60:16-21.

16. Diretoria Técnica de Gestão, Secretaria de Vigilância em Saúde, Ministério da Saúde. Dengue: diagnóstico e manejo clínico: adulto e criança. 4a Ed. Brasília: Ministério da Saúde; 2013.

17. Cordeiro MT, Silva AM, Brito CA, Nascimento EJ, Magalhães MC, Guimarães GF, et al. Characterization of a dengue patient cohort in Recife, Brazil. Am J Trop Med Hyg 2007; 77:1128-34.

18. Morens DM, Halstead SB, Repik PM, Putvatana R, Raybourne N. Simplified plaque reduction neutralization assay for dengue viruses by semimicro methods in BHK-21 cells: comparison of the BHK suspension test with standard plaque reduction neutralization. J Clin Microbiol 1985; 22:250-4.
19. Castanha PM, Cordeiro MT, Martelli CM, Souza WV, Marques Jr. ET, Braga C. Force of infection of dengue serotypes in a population-based study in the northeast of Brazil. Epidemiol Infect 2013; 141:1080-8.

20. Yoon IK, Rothman AL, Tannitisupawong D, Srikiatkhachorn A, Jarman RG, Aldstadt J, et al. Underrecognized mildly symptomatic viremic dengue virus infections in rural Thai schools and villages. J Infect Dis 2012; 206:389-98.

21. Villabona-Arenas CJ, de Oliveira JL, Capra CS, Balarini K, Loureiro M, Fonseca CR, et al. Detection of four dengue serotypes suggests rise in hyperendemicity in urban centers of Brazil. PLoS Negl Trop Dis 2014; 8:e2620.

22. Kuan G, Gordon A, Aviles W, Ortega O, Hammond SN, Elizondo D, et al. The Nicaraguan pediatric dengue cohort study: study design, methods, use of information technology, and extension to other infectious diseases. Am J Epidemiol 2009; 170:1209.

23. Morrison AC, Minnick SL, Rocha C, Forshey BM, Stoddard ST, Getis A, et al. Epidemiology of dengue virus in Iquitos, Peru 1999 to 2005: interepidemic and epidemic patterns of transmission. PLoS Negl Trop Dis 2010; 4:e670.

24. Fewtrell MS, Kennedy K, Singhal A, Martin RM, Ness A, Hadders-Algra M, et al. How much loss to follow-up is acceptable in long-term randomised trials and prospective studies? Arch Dis Child 2008; 93:458-61.

25. Kristman V, Manno M, Cote P. Loss to follow-up in cohort studies: how much is too much? Eur J Epidemiol 2004; 19:751-60.

26. Woods CR. False-positive results for immunoglobulin M serologic results: explanations and examples. J Pediatric Infect Dis Soc 2013; 2:87-90.

27. UNICEF/UNDP/World Bank/WHO Special Programme for Research and Training in Tropical Diseases. Evaluation of commercially available antidengue virus immunoglobulin $M$ tests. Geneva: World Health Organization; 2009. (Diagnostics Evaluation Series, 3).

28. Prince HE, Matud JL. Estimation of dengue virus IgM persistence using regression analysis. Clin Vaccine Immunol 2011; 18:2183-5.

29. Vaughn DW, Green S, Kalayanarooj S, Innis BL, Nimmannitya S, Suntayakorn S, et al. Dengue in the early febrile phase: viremia and antibody responses. J Infect Dis 1997; 176:322-30.

30. Peeling RW, Artsob H, Pelegrino JL, Buchy P, Cardosa MJ, Devi S, et al. Evaluation of diagnostic tests: dengue. Nat Rev Microbiol 2010; 8:S30-8.

31. Kassanjee R, McWalter TA, Welte A. Short communication: defining optimality of a test for recent infection for HIV incidence surveillance. AIDS Res Hum Retroviruses 2014; 30:45-9. 


\section{Resumo}

Casos de dengue têm aumentado em grupos etários mais jovens no Brasil. Anticorpos antidengue maternos podem exercer efeito protetor nos primeiros meses de vida, mas seu declínio pode aumentar o risco de dengue grave. Uma coorte de nascimento prospectiva foi estabelecida na cidade do Recife, Pernambuco, Brasil, entre 2011-2012, para determinar a incidência de infecção sorotipo-específica do dengue e cinética dos anticorpos antidengue materno-transferidos nos primeiros anos de vida. Este artigo descreve o desenho, os métodos e resultados preliminares deste estudo de coorte. Trezentas e cinquenta e quatro crianças foram acompanhadas clínico e laboratorialmente por dois anos, com $15 \%$ de perdas de seguimento. A taxa global de novas infecções foi de aproximadamente $10 \%$ na coorte de crianças no primeiro ano de seguimento. Informações sobre a força de infecção sorotipo-específica do dengue nos primeiros anos de vida, bem como a avaliação da cinética de anticorpos materno-transferidos poderão contribuir para a compreensão da etiopatogenia da doença.

Imunização Passiva; Dengue; Estudos de Coortes

\section{Resumen}

Los casos de dengue han aumentado en los grupos de edad más jóvenes en Brasil. Los anticuerpos antidengue maternos pueden ejercer un efecto protector en los primeros meses de vida, pero su decremento puede aumentar el riesgo de dengue grave. Una cohorte de nacimientos prospectiva se estableció en la ciudad de Recife, Pernambuco, Brasil, entre 2011-2012, para determinar la incidencia de infección serotipo-específica de dengue y la cinética de los anticuerpos antidengue materno-transferidos durante los primeros años de vida. Este artículo describe el diseño, los métodos y resultados preliminares de este estudio de cohorte. 354 niños fueron acompañados clínicamente y en laboratorio durante dos años, con un 15\% de pérdidas en el seguimiento. La tasa global de nuevas infecciones fue de aproximadamente un $10 \%$ en la cohorte de niños durante el primer año de seguimiento. La información sobre la fuerza de infección serotipo-específica del dengue en los primeros años de vida, así como la evaluación de la cinética de los anticuerpos maternotransferidos, podrá contribuir a la comprensión de la etiopatogenia de la enfermedad.

Inmunización Pasiva; Dengue; Estudios de Cohortes
Submitted on 18/Jun/2015

Final version resubmitted on 16/Oct/2015 Approved on 28/Oct/2015 